\title{
PRECARIOUS EMPLOYMENT IN THE NEW ZEALAND CALL CENTRE INDUSTRY
}

\author{
Zeenobiyah Naadiyah Hannif \\ Newcastle Business School \\ University of Newcastle, NSW, Australia \\ Felicity Lamm \\ Department of Management and Employment Relations \\ University of Auckland, New Zealand
}

\begin{abstract}
Precarious employment is an increasingly prevalent phenomenon in contemporary labour markets. Research on the call centre industry has not only identified a growing use of non-standard employment arrangements, but also evidence to indicate that precariousness may be a feature of employment in this industry. Despite this evidence, however, there is still little known about the extent to which precarious employment is an integral part of the NZ call centre context. In addition, there has been scant research on the individual experiences of non-standard workers employed in the call centre industry. This paper aims to address the gaps in the literature by essentially 'marrying' these three broad areas of research. A framework for measuring precariousness is introduced and examined in relation to two case study call centres, selected to facilitate a comparative approach. Based on in-depth interviews with case study participants and key stakeholders, this paper examines the applicability of this framework to the NZ call centre context. Key findings from the study indicate that precarious employment is indeed a phenomenon that affects non-standard workers in the $N Z$ call centre industry. A number of policy concerns are raised through the data, particularly where the incidence of precarious employment is associated with the lack of organisational compliance with employment legislation.
\end{abstract}

\section{Introduction}

Call centres have emerged as new workplace forms, where non-standard employment is increasingly being accepted as the 'norm' (Hunt, 2004). Non-standard employment forms comprise all employment arrangements that fall outside the characteristics of the traditional 'standard' employment model where work is typically ongoing and regular; conducted over 40 daylight hours between Monday and Friday, and based on strong employer-employee relationships. Non-standard forms, therefore, incorporate all employment arrangements that are not fulltime, regular, or permanent, including work classed as part-time, casual, temporary, fixed term, seasonal, on-call, and contractual, as well as shift work and holding multiple jobs (Morley, Gunnigle and Haraty 1995; Brosnan and Walsh 1996; Barker and Christensen 1998; Carroll 1999; Horwitz, Allan and Brosnan 2000; Mangan 2000; Sheridan and Conway 2001). Much of the concern expressed by call centre researchers is, therefore, related to the negative outcomes associated with the use of non-standard employment arrangements in these workplaces. In particular, non-standard arrangements are perceived to be associated with low levels of pay, little job security, unsocial working hours, little access to non-wage benefits and entitlements, and limited opportunities for training and development; conditions that researchers have associated with the phenomenon of precarious employment (see Brosnan 1995; Tregaskis 1997; Kramar 1998; Burgess and Strachan 1999; Markey Hodgkinson and Kowalczyk 2002; Rosenberg and Lapidus 1999; Quinlan, Mayhew and Bohle 2001; Tucker 2002; Future of Work Review [FOW] 2002).

Despite the frequent use of these non-standard arrangements in call centre workplaces (see Richardson and Marshall, 1999; Hutchinson, Purcell and Kinnie 2000a; Watson, Bunzel, Lockyer and Scholarios 2000; Australian Communications Association [ACA] 2002; Paul and Huws 2002; Union Research Centre for Organisation and Technology [URCOT] 2002; ACA 2003), and call centre work being rendered 'low quality' employment by various researchers (see Taylor and Bain 1999; Gilmore and Moreland 2000; Richardson, Belt and Marshall 2000; Batt and Moynihan 2002; Deery and Kinnie 2002), the phenomenon of precarious employment as it occurs in the call centre context remains largely unexplored.

This paper will attempt to address this gap in the literature by examining: to what extent is employment in the New Zealand call centre industry precarious? In setting the context for this paper, the concept of 'precariousness' will be introduced, alongside the 'Tucker' model as a framework for measuring the phenomenon. The case study research design will be briefly outlined, followed by an overview of the two case studies and a discussion on the key findings.

\section{The Framework}

Despite precarious employment becoming an increasingly prominent feature of contemporary labour markets, there exists no commonly accepted definition of the term. The 
literature can, however, be divided into three distinct camps, in which "precariousness" in employment is viewed as either:

- A term that is universally interchangeable with "nonstandard" employment;

- A label that can be attached to certain categories of non-standard employment (e.g. casual, temporary);

- A complex term that is multidimensional in its measurement, and thus can affect any employment form, standard or non-standard.

The definition applied to this study reflects the third category, an approach supported by Rodgers and Rodgers (1989) and Burgess and Campbell (1998). Once an appropriate definition was identified, a framework was necessary to measure the phenomenon. The 'Tucker' framework was adopted to fulfil this purpose. Comprising ten potential indicators, this framework (see Table 1) was developed, to assess precariousness in any employment arrangement. It is important to note that this model was developed specifically for the NZ context, hence, several of the indicators relate directly to the legal entitlements of non-standard workers as 'employees' in NZ. Tucker (2002) states the framework operates as a continuum, so emphasis is placed on determining the extent to which employment can be considered precarious. Tucker (2002) also suggests that an assessment of precariousness should extend to encompass worker characteristics and preferences. Working arrangements will therefore, be examined in relation to worker characteristics and preferences, allowing a more comprehensive evaluation of what constitutes precariousness.

\section{Table 1: Tucker's Ten Potential Indicators of} Precariousness

1. The job can be terminated with little or no prior notice by the employer.

2. Hours of work are uncertain or can be changed at will by the employer:

3. Earnings are uncertain or irregular:

4. Functions of the job can be changed at will by the employer:

5. There is no explicit or implicil contract for ongoing employment:

6. There is, in practice, no protection against discrimination, sexual harassment, unaceeptable working practices;

7. The job is low income-at or below the minimum wage;

$x$ There is little or no access to 'standard' non-wage employment benefits such as sick leave, domestic leave, bereavement leave or parental leave;

9. There is limited or no opportunity to gain and retain skills through access to education and iraining:

10. The task performed or the health and safety practices at the workplace make the job dangerous/ unhealthy.

\section{Research Design}

A qualitative paradigm was considered the most appropriate for examining the individual experiences of call centre employees, as it caters for the multiplicity of 'reality' captured through subjective experiences, and allows for thorough analyses of phenomena through the exploration of underlying meanings (Marshall and Rossman 1995). As a key qualitative approach, a case study methodology was adopted because of its usefulness for research that is exploratory in nature (Yin 1994). The case study approach was also an attractive option for this study because it allowed for an investigation of precarious employment within the context in which it occurred (Marshall and Rossman 1995).

Two call centres (TELI \& MESO) were subsequently selected as case studies (from a pool of five call centres that had expressed an interest in being involved in the research). The decision to select the two cases studies was based on the fact that they differed significantly from one another in terms of their organisational structure, work design, and employment practices. More specifically, the selected case studies epitomised the high level of diversity that exists in the New Zealand call centre industry, and allowed the researcher to determine the extent to which call centre employees' experiences converged or differed on the basis of intrinsic organisational factors.

Five data collection tools and four sources were used as part of a triangulated approach (see Table 2); the use of multiple perspectives allows the researcher to "overcome the intrinsic bias" associated with single method studies (Ackroyd and Hughes 1981: 137). As the primary data collection tool, semi-structured interviews were conducted with 50 case study participants, and 9 stakeholders (see Table 3). Tucker's ten key indicators of precariousness were modified into questions, allowing the researcher to examine the experiences of non-standard call centre employees whilst simultaneously determining the extent to which their work could be considered precarious.

\section{Table 2: Matrix of Method and Data Triangulation}

\begin{tabular}{|l|c|c|c|}
\hline \multicolumn{1}{|c|}{ Methods } & Workers & $\begin{array}{c}\text { Supervisors/ } \\
\text { Managers }\end{array}$ & Stakeholders \\
\hline Interviews & $\checkmark$ & $\checkmark$ & $\checkmark$ \\
TELI & 29 & $\begin{array}{r}2 / 1 \\
\text { MESO }\end{array}$ & \\
\hline Email & $\checkmark$ & $\checkmark$ & \\
\hline $\begin{array}{l}\text { Document } \\
\text { Analysis }\end{array}$ & $\checkmark$ & $\checkmark$ & $\checkmark$ \\
\hline Archival \\
Analysis & & $\checkmark$ & $\checkmark$ \\
\hline Direct \\
Observations & $\checkmark$ & $\checkmark$ & \\
\hline
\end{tabular}


Table 3: Stakeholders Interviewed

\begin{tabular}{|l|l|}
\hline \multicolumn{1}{|c|}{ Organisation } & \multicolumn{1}{c|}{ Participants } \\
\hline Occupational Safety \&Health Service & 1 Advisor \\
\hline Service \& Food Workers Union & $\begin{array}{l}\text { 1 Union Organiser, } \\
\text { 3 Delegates }\end{array}$ \\
\hline Finance \& Information Workers Union & 1 Union Organiser \\
\hline NZ Council of Trade Unions & 1 Editor \\
\hline $\begin{array}{l}\text { Electro-technology Industry Training } \\
\text { Organisation }\end{array}$ & 1 Advisor \\
\hline Labour Market Policy Group & 1 Analyst \\
\hline
\end{tabular}

\section{Findings}

\section{Organisational Features}

The two call centres involved in the study differed significantly in terms of their structure, work design; and employment practices. This section will comparatively outline the two case studies in terms of their organisational structure, work design, and employment practices and place them in context relative to call centres in the NZ call centre industry'.

\section{Organisational Structure}

In short, TELI is the larger and more established of the two call centres. This call centre is the customer service division of a large company with multiple independent branches throughout NZ and Australia. MESO on the other hand, is a small call centre that has been operating in the NZ business environment for the past 14 years. As a division of a large multinational Market Research organisation, MESO currently services the NZ and Australian markets.

MESO's size makes it more representative of NZ call centres. It fits into the second most common size category ( $26-50$ seats) estimated to be occupied by $26 \%$ of NZ call centres (see ACA 2002). Call centres of TELI's size on the other hand, are rarer, representing only $6 \%$ of NZ call centres. The sectors in which these two call centres operate are a minority in terms of NZ industry data, where Government and IT\&T dominate.

\section{Table 4: Organisational Structure of TELI \& MESO}

\begin{tabular}{|l|l|l|l|}
\hline \multicolumn{1}{|c|}{ TELI } & \multicolumn{1}{|c|}{ MESO } & NZ Industry Data \\
\hline $\begin{array}{l}\text { Industry } \\
\text { Sector }\end{array}$ & Sports & $\begin{array}{l}\text { Market } \\
\text { research }\end{array}$ & $\begin{array}{l}\text { Majority Govt \& } \\
\text { IT\&T }\end{array}$ \\
\hline $\begin{array}{l}\text { Nature of } \\
\text { industry }\end{array}$ & Stable & Erratic & N/A \\
\hline Structure & In-house & Outsourcer & $\begin{array}{l}\text { Growing demand } \\
\text { for out-sourcers }\end{array}$ \\
\hline Age & 38 years & 14 years & No data available \\
\hline Size & 160 Seats & 34 Seats & Mean: 32 Seats \\
\hline
\end{tabular}

\section{Work Design}

The nature of the work within TELI is inbound, with staff receiving calls through their head-sets from an automated queuing system. The nature of this particular industry dictates the inflow of calls being heavier during certain hours and particular seasonal periods. The industry in which TELI operates is however relatively stable, and presents little competitive pressure. Work within MESO is outbound, with workers manually placing calls to either a random or specifically targeted population group. The nature of the market dictates that campaigns change regularly. Although products and scripts vary, the particular functions of the job remain constant.

Table 5: Work Design in TELI and MESO

\begin{tabular}{|c|c|c|c|}
\hline & TELI & MESO & $\begin{array}{c}\text { NZ Industry } \\
\text { Data }\end{array}$ \\
\hline $\begin{array}{l}\text { Work } \\
\text { Function }\end{array}$ & $\begin{array}{l}\text { Customer } \\
\text { service }\end{array}$ & $\begin{array}{l}\text { Market } \\
\text { Research }\end{array}$ & $\begin{array}{l}\text { Customer Service: } \\
47 \% \\
\text { Market Research: } \\
1 \%\end{array}$ \\
\hline $\begin{array}{l}\text { Flow of } \\
\text { Calls }\end{array}$ & Inbound & Outbound & \\
\hline $\begin{array}{l}\text { Types of } \\
\text { calls }\end{array}$ & Consumer & $\begin{array}{l}\text { Business \& } \\
\text { Consumer }\end{array}$ & $\begin{array}{l}\text { Consumer: } 28 \% \\
\text { Business: } 12 \% \\
\text { Both: } 60 \%\end{array}$ \\
\hline
\end{tabular}

\section{Employment Practices}

TELI undertakes one large recruitment intake each year, preferring tertiary students and middle aged women for call centre positions. The organisation does, however, feature a relatively high concentration of workers over the age of 50 years. The highest turnover rates are amongst students who move on after completion of their studies; middle-aged women on the other hand, have the strongest staying power. The Service and Food Workers Union have a relatively strong presence within this organisation, representing almost $60 \%$ of the staff. Any changes negotiated by the union are introduced into the general agreement covering all workers.

Four large recruitment intakes occur annually within MESO, although recruitment also occurs sporadically as the need arises, particularly through informal means such as word-of-mouth referrals. Given the recruitment methods, the majority of MESO employees are secondary or tertiary students. Employee retention is identified as the most pertinent issue within this organisation. Turnover is linked specifically to fluctuations in workloads, and is significant during long periods of inactivity.

A key feature these case studies share with the wider call centre industry is the use of part-time and casual staff. MESO relies exclusively on casual call centre operators, while TELI uses a combination of regular part-timers and casual staff, although these workers are referred to as "cores" and "non-cores" respectively. 
Table 6: Employment Features in TELI and MESO

\begin{tabular}{|c|c|c|c|}
\hline & TELI & MESO & NZ Industry Data \\
\hline Total Workforce & $\begin{array}{l}177 \\
\text { Core (part-timers): } 57(32 \%) \\
\text { Non-core (casuals): } 120(68 \%)\end{array}$ & $\begin{array}{l}132 \\
\text { Casuals : } 100 \% \text { of workforce }\end{array}$ & $\begin{array}{l}81 \% \text { of NZ call centres employ } \\
\text { casuals/part-timers } \\
\text { Mean: } 11 \text { casuals/ part-timers } \\
\text { employed per NZ call centre. }\end{array}$ \\
\hline Gender Ratios & $\begin{array}{l}\text { Males: } 38(22 \%) \\
\text { [8 core/ } 30 \text { non-core] } \\
\text { Females: } 139(78 \%) \\
{[49 \text { core/ } 90 \text { non-core] }}\end{array}$ & $\begin{array}{l}\text { Males: } 49(37 \%) \\
\text { Females: } 83(63 \%)\end{array}$ & \\
\hline Union Presence & $\begin{array}{l}105 \text { staff members }(59 \%) \text { unionised by Service } \\
\text { and Food Workers Union. } \\
\text { [39 core staff/ } 66 \text { non-core staff unionised] } \\
{[17 \text { males/ } 88 \text { females unionised] }}\end{array}$ & No union presence on site & $\begin{array}{l}40 \% \text { of call centres have unionised } \\
\text { staff; } \\
\text { Average industry unionisation rate: } \\
13 \% \\
3 \text { major unions represent } \\
\text { Call centres in NZ: FINSEC, PSA } \\
\text { and SFWU }\end{array}$ \\
\hline Tenure & $\begin{array}{l}\text { Core: } 5-38 \text { years: } \\
\text { Non-Core: } 3 \text { weeks - } 7.5 \text { years }\end{array}$ & 3 weeks -4 years & No data available \\
\hline \multicolumn{4}{|l|}{ Employee Age } \\
\hline & $Q$ & $\%$ & No data available \\
\hline 15.17 & 0 & 36 & \\
\hline $18-24$ & 72 & 44 & \\
\hline $25-34$ & 36 & 18 & \\
\hline $35-39$ & 14 & 10 & \\
\hline $40-49$ & 23 & 12 & \\
\hline $50-59$ & 18 & 10 & \\
\hline \multirow[t]{2}{*}{$60+$} & $14 \quad 7$ & 2 & \\
\hline & $\begin{array}{l}\text { Core: All late } 40 \text { s-late } 60 \mathrm{~s} \text {. } \\
\text { Non-Core: } 20-58 \text { years }\end{array}$ & & \\
\hline
\end{tabular}

\section{Discussion}

The employment experiences of call centre workers in the two case studies were documented in terms of Tucker's ien indicators of precariousness. The findings from the study revealed a number of important themes and possible implications. These are discussed below.

\section{Can The Job Be Terminated With Little or No Prior Notice by the Employer?}

The prospect of employment termination affects the different groups of non-standard workers in these organisations disproportionately. Core employees from TELI are least likely to have their agreements terminated, followed by non-cores, and finally, the casuals from $\mathrm{MESO}$; a fact that is clearly reflected in the average tenure of these groups of workers.

MESO management did not allow employees to have their agreements formally terminated because of fear that employees may seek personal grievance claims. This lack of confidence in the outcomes of the personal grievance procedures under the Employment Relations Act, 2000, did not, however, prevent employees from being disadvantaged in other ways. For example, supervisors stated that employees are completely excluded from further work opportunities if their performance is found to be lacking; with no opportunity to explain or improve their performance, a clear breach of employer's good faith obligations. Section 66 of the Employment Relations Act is also being breached, because of the employers' failure to specify when exactly the employment agreement will end. This is particularly problematic as MESO's employment agreement states that two weeks notice is required when terminating agreements.

Within TELI, the biggest concern was the growing use of self-service technologies and the worry that most of these workers have low skills and scarce opportunities for training and development (see ACA 1998; Barker and Christensen 1998a; URCOT 2000; Deery and Kinnie 2002; Paul and Huws 2002). It is questionable as to whether these employees will be able to find gainful employment elsewhere, and which occupations they will be forced into next.

They could do something really small, and we just won't call them back anymore, we can't tell them they're not employed with us anymore, we just stop calling and say "no" even if there is work there (MESO: Supervisor). 


\section{Are the Hours of Work Uncertain and/or Can They be Changed at Will by the Employer}

The most significant factor that emerged in terms of this indicator was that of uneven workloads. From the findings, it is clear that not only are the working hours within both organisations subject to varying degrees of uncertainty and irregularity (depending on the employment agreement), but they are also subject to being changed at will by the employer. This is more likely to occur in the small call centre. As the data suggests, keeping working hours casual is the only means by which this organisation is able to respond to changes in the marketplace.

Although call centre organisations look to casual employment in order to keep ahead of competitive pressures, the case study data indicates that greater flexibility in these respects only increases the amount of control employers have over the utilisation of labour (also refer to Burgess and Strachan 1999). It is also apparent that flexible employment arrangements have largely compromised the needs of employees, leaving them subject to the most severe outcomes (Kramar 1998; Sheridan and Conway 2001). In terms of the case study participants, this includes having access to fewer hours than they need or prefer. These workers are also penalised in terms of their earnings given that their incomes depend on the number of hours they work (Tregaskis 1997; Paul and Huws 2002), conditions that are not only strongly predisposed to stress (URCOT 2000; OSH Service 2003) but are also likely to contribute to the high rates of turnover that characterise this industry (URCOT 2000; Paul and Huws 2002).

They can call on Monday and give me shifts, but then again I won't get anything for a while (TELI: NonCore Employee).

\section{Are Employees' Earnings Uncertain or Irregular?}

The case study data indicates varying levels of income uncertainty and irregularity between individuals from the two call centres. Core TELI workers had the most regular incomes, followed by non-core TELI workers and finally, casuals from MESO. It was apparent, however, that none of the case study participants, employed as either noncore workers at TELI or casual workers at MESO, relied on call centre work as a sole source of their income. Rather, employment was pursued in these call centres as a means of supplementing other income sources (also refer to Mangan, 2003; Richardson et al 2000; URCOT 2000; Paul and Huws 2002; Brosnan 1995; Markey et al 2002).

Our earnings are definitely uncertain and irregular, one week you'll work and maybe for a month you won't (MESO: Employee).

\section{Can the Functions of the Job Be Changed at Will by the Employer?}

According to the Tucker framework, an employee who is highly susceptible to having their work functions changed at will by the employer is in a precarious working arrangement. The data from the case studies however, challenges the applicability of this indicator to the call centre context. Firstly, interviews and direct observations indicate that although workers have minimum control over their particular work functions, these are seldom subject to modification. On the rare occasion that variations do occur, these are offered to employees as a reward, rather than imposed on workers as a means of control. Furthermore, rather than view these changes negatively, there was a general preference amongst all 43 of the employees interviewed for greater variety in the functional tasks, particularly given the 'monotony', 'repetitiveness' and 'boredom' associated with the nature of the work (refer to: ACA, 1998; Taylor and Bain 1999; Bain et al 2000; Gilmore and Moreland 2000; Hutchinson et al 2000; Paul and Huws 2000; Richardson et al 2000; Batt and Moynihan 2002; Deery and Kinnie 2002; Holmon 2002).

Its very monotonous, boring and repetitive, you're dialling and saying the same things over and over again to the same people who don't want to talk to you (MESO: Employee).

\section{Is There an Explicit or Implicit Contract for Ongoing Employment?}

The more stable and regular nature of employment in TELI is reflected in a stronger sense of employment continuity. Employees expect work to be provided on an ongoing basis, while at the same time, there is an expectation by employers that workers will accept shifts as they are offered. Although this relationship is less explicit in the case of non-core workers, there is still a mutual understanding between the parties that the employment relationship will be ongoing.

The employment agreement within MESO, on the other hand, makes it clear that employees cannot expect employment on an ongoing basis; confirming what Watson et al (2000) describe as the loosening of the employer-employee relationship in the call centre industry. This 'arm-length' relationship, however, does not apply to all MESO employees. Rather, there are a number of workers (5 out of the 14 interviewed) who appear to have strong, ongoing relationships with the organisation, reflected in their relatively long tenures (114 years) and the shorter work gaps they experience. According to Australian researchers (e.g. Burgess 1997; Owens 2001; Watts 2000) these workers can be classified as 'long-term casuals' because their employment relationships are more akin to ongoing employment.

The employment practices of MESO also contravene section (66) of the ERA in terms of what constitutes a 'casual' employment relationship. The case study data 
suggests these employees are often required to work hours that exceed the work-load typically required of fulltimers, however, they are still made subject to the same employment agreement as the true casuals (refer to Burgess 1997; Rudman 2000; Owens 2001; Watts 2001).

1 have no idea if they'll call me after this campaign, some people have been here for ages but they can drop you anytime, they don't owe us anything so we cant expect it (MESO: Employee).

\section{Is There, in Practice, Any Protection Against Discrimination, Sexual Harassment, and Unacceptable Working Practices?}

MESO had nothing in the way of even the most basic policies and practices in place, to protect employees against discrimination, sexual harassment, and unacceptable working practices in the workplace. Supervisors stated that employees are required to use their "common-sense" in dealing with these concerns, while the manager stated the high use of casual workers diminished the significance of such issues. This managerial perspective is typical in the call centre industry, more so when dealing with outsourcers (Wallace et al 2000; Paul and Huws 2002).

There is also evidence to indicate that the absence of such policies may be influenced by the lack of unionism in this call centre. As research suggests, the maintenance of even the most basic rights come under threat in the absence of collective representation (Burgess and Strachan 1999; URCOT 2000; Bergstrom 2001; Houseman 2001; Tucker 2002). Union organisers however, indicate they experience significant barriers in gaining access to call centre workers. In particular, tight monitoring of employees and the high use of non-standard workers in these workplaces makes it difficult for union organisers to open lines of communication, in order to organise meetings, and increase membership; factors which ultimately leave these employees highly susceptible to undesirable working practices.

On the other-hand, protective policies for discrimination and harassment are comprehensively detailed in TELI. Visual aids are presented throughout the workplace detailing what constitutes harassment and procedures for dealing with these issues. The organisation also takes part in an Employee Assistance Program and provides referrals to counsellors as necessary.

The case study data indicates that levels of unionisation may have influenced the OHS policies present in the two call centres. The emergence of two distinct findings from TELI in relation to unionisation, however, appears more significant. Firstly, non-core employees had lower levels of unionisation than core employees ${ }^{2}$, which may confirm the difficulties experienced by unions in getting alongside the more contingent work-force. Secondly, non-core employees were less informed than core employees about policies and practices regarding discrimination, harassment and unacceptable working practices; which may further emphasise the role unions can play in improving working conditions for call centre employees (Frenkel et al 1998; URCOT 2000; Paul and Huws 2002). More significantly, these findings highlight the need for union involvement where lower scale non-standard workers (e.g. casuals) are involved (Lipsig-Mumme 1998; Quinlan et al 2000, 2000a; URCOT 2000; Houseman 2001; Tucker 2002; Quinlan 2003, 2003a). The literature along with the case study data confirms that these workers not only have the least knowledge about their rights, but are also the most susceptible to exploitation (Burgess and Strachan 1999; Smithson and Lewis 2000; Vosko 2000; Zeytinoglu and Muteshi 2000; Bergstrom 2001; Houseman 2001; Tucker 2002).

People aren't here for long, so those types of things don't happen (MESO: Manager).

The union takes care of things like that for us, they have good access to management (TELI: Employee)

\section{Is the Job Low Income-At/Below the Minimum Wage?}

The wage rates within both call centres rates are above the minimum wage as specified by the Minimum Wage Act 1983 (youth rate: \$7.20; over 18 years: \$9.00). Nevertheless, all 43 of the employees interviewed felt their wage rates provided insufficient compensation for the nature of the work they do, particularly given the unsocial hours they are typically required to work. These responses are consistent, with the call centre literature and statements made by key stakeholders from the NZ call centre industry.

\section{Table 5: Hourly Wage Rates According to Employment Agreements in MESO and TELI}

\begin{tabular}{|c|c|c|c|}
\hline MESO & $\mathrm{p} / \mathrm{h}$ & TELI & $\mathrm{p} / \mathrm{h}$ \\
\hline After $6 \mathrm{mths}$ service & $\$ 12$ & Core & $\$ 13.42$ \\
\hline Experienced & $\$ 11$ & Non-core & $\$ 12.23$ \\
\hline Un-experienced & $\$ 10$ & & \\
\hline
\end{tabular}

The extant literature (e.g Taylor and Bain 1999; Bain et al 2000; Gilmore and Moreland 2000; Hutchinson et al 2000; Richardson et al 2000; Batt and Moynihan 2002; Deery and Kinnie 2002; Holmon 2002) suggests that workers are often paid poorly in call centres because of the low status image attached to the nature of the work. According to Buchanan and Koch-Schulte (2000), this is influenced by the gender dimensions operating in these workplaces, and the fact that the occupation is increasingly being "feminised" as unskilled, part-time and low-paid employment. The case study data, and the literature further confirm these findings; not only are call centres being defined as female dominated workplaces, but the skills and the nature of the work in these environments are also commonly classified as 'women's work' (Frenkel et al 1998; Richardson and Marshall 1999; Buchanan and Koch-Schulte 2000; Hutchinson et al 
2000; Richardson et al 2000; Deery and Kinnie 2002; Shire et al 2002).

An alternative explanation may be the high use of nonstandard workers, who, as such are disadvantaged in terms of the incomes they earn (see Burgess 1997; Tregaskis 1997; Kramar 1998; Burgess and Strachan 1999; Rosenberg and Lapidus 1999; FOW 2002). This appears to be the case within the two call centres, where the workforces are entirely made up of non-standard employees. However, the wage rates fall short of the industry benchmark of $\$ 15.40$ (see ACA 2002).

The most they get is $\$ 12 \mathrm{p} / \mathrm{h}$ which is crumby for what they do, they deserve more (MESO: Supervisor).

We should get penal rates for Saturdays, Sundays and afternoons, then I'd be happy (TELI: Core Employee).

\section{Is There Any Access To 'Standard' Non-Wage Employment Benefits Such As Sick Leave, Domestic Leave, Bereavement Leave Or Parental Leave?}

MESO's employment agreements specify annual holiday pay as the only non-wage entitlement, whereas TELI's includes access to bereavement leave, parental leave, sick leave, holiday pay and redundancy pay. Core employees within TELI, however, have more access to these entitlements than non-core employees, indicating that those experiencing the lowest levels of security and certainty in their employment agreements, have access to the most limited range of non-wage employment benefits and entitlements.

There are a number of issues that stand out in terms of this data. Firstly, 10 employees from MESO and 10 noncore employees from TELI felt their exclusion from more non-wage benefits was justified because of the casual nature of their employment. This finding is consistent Smithson and Lewis' (2000) conclusion that as well as accepting higher levels of insecurity in the labour market, young workers express a lower expectation and sense of entitlement to non-wage benefits, and thus, are less inclined to express dissatisfaction when access is denied.

Older workers from both organisations reacted very differently towards this issue. For instance, all of the 9 core workers interviewed from TELI, stated that although they felt they deserved the entitlements specified in the employment agreement, they were unhappy that the employment agreement failed to include additional benefits that would typically be made available for fulltimers. These employees argued that the nature of their employment is far more akin to permanent full-time work than the employers recognised. All of these employees worked hours almost equivalent to full-time work (although these hours are spread over a greater number of days) and had served the organisation for over 10 years (Longest tenure 38 years) and indicated intentions of remaining in the organisation indefinitely or until retirement. Furthermore, all of the interviewed core workers relied on the job as a main source of income despite the relatively low wage rates they are subject to, suggesting levels of commitment that are comparable to those on permanent fulltime agreements (Hipple and Stewart 1996; Houseman 1999; Rosenberg and Lapidus 1999; Horwitz et al 2000; Zeytinoglu and Muteshi 2000; Smithson and Lewis 2000; Cranford et al 2003).

The 9 core workers interviewed from TELI also expressed dissatisfaction at the absence of penal rates, particularly given the number of unsocial hours they are required to work. The call centre literature (e.g. Kinnie, Hutchinson and Purcell 2000; Richardson et al 2000; URCOT 2000; Paul and Huws 2002) suggests these responses are typical of the industry, especially with the extension of call centre operating hours and the growing use of non-standard workers. Nevertheless, the lack of compensatory remuneration in these respects is troubling, more so given the disadvantaged status of these individuals in the labour market and their limited labour market choices. In particular, there is concern that the employers are using non-standard employment status in order to escape having to pay these core workers a more extensive range of employment benefits (Burgess 1997; Tregaskis 1997; Christensen 1998; Allan 2000; URCOT 2000; Murtough and Waite 2001; Reilly 2001; Paul and Huws 2002; Tucker 2002; Quinlan 2003a).

The ladies in there between 55-65 couldn't get a job elsewhere, most have worked here for over 25 years; but if they walked out the company would give them nothing (TELI: Core Employee)

\section{Is There Any Opportunity To Gain and Retain Skills Through Access To Education and Truining?}

Unlike call centres in the ACA 2002 industry analysis, there is no ongoing training made available within these case studies, despite the interest shown by some of the employees. Nevertheless, the absence of training in these case studies is considered by a number of researchers as a typical feature of this industry (see ACA 1998; Richardson et al 2000; URCOT 2000; Deery and Kinnie 2002; Paul and Huws 2002). Data from the case studies suggests two main reasons for the lack of training.

Given the low value placed on call centre workers roles, and the large supply of unskilled labour ready to replace them, there remains little incentive for organisations to replenish and develop their skills (Tresgaskis 1997; (Barker and Christensen 1998a; Nollen and Axel 1998; Bergstrom 2001). This inevitably creates high rates of turnover, which only further limits the organisations' capacity to provide training initiatives. Again, this supports Wallace's et al (2000) criticism of the absence of people management skills in these organisations. Employees are expected to expend their efforts to meet the needs of the organisation, despite the organisation doing little for employees.

A key industry stakeholder indicates the absence of training in call centres workplaces is associated with the 
fact that the nature of the work is considered "low skilled". Interestingly, 36 out of the total 43 employees interviewed from the case studies confirmed this theory, stating that the limited range of skills required for the work justified their exclusion from such opportunities. There is, however, evidence in the literature to suggest that the 'low skilled' image associated with call centre work is being reinforced by the lack of training in these workplaces. In other words, these perceptions are contributing to what can be considered as essentially a 'spiral' effect, where lack of training causes the work to remain low skilled, and the low skilled nature of the work in turn, leads to the conclusion that there is no need for training.

The literature is consistent not only in emphasising the absence of training in call centres, but also the immediacy of these issues, For instance, URCOT (2000) suggests that training and education in call centres is critical because future projections indicate the widespread use of more sophisticated technologies, and the provision of an even wider ranger of call centre services (Prabhkar, Sheehan and Coppett 1997; ACA 2003). Without improved training, URCOT (2000: 6) notes there is significant risk that the continuing boom "will leave behind a pool of unskilled and semi skilled workers sceking employment in a multi-skilled industry".

That's not something they do here; we're just here to do the job, there's no extras. (TELI: Core Employee).

\section{Does the Nature of the Task Performed or do the Health and Safetr Practices in the Norkplace make the Job Dangerous Or Unhealthy?}

There is a considerable amount of evidence in the literature to suggest that the tasks performed and the health and safety policies and practices evident in call centre workplaces may put the health and safety of employees at risk. For instance, call centre employees do not only face the possibility of harm in terms of the specific work functions they perform (for example, simultancously using word processing and telephony (quipment), but also in terms of their specific working environment (e.g. equipment design). Case study participants were asked to identify any adverse impacts call centre work had had on their physical or psychological health. The three key issues identified by respondents, along with the number of respondents identifying these from each call centre are displayed in Table 6 below. Please note that respondents were free to identify any number of health and safety issues.

The case study data raises a number of concerns, particularly in terms of the specific health and safety policies and practices of the two organisations. Firstly, it is clear that the small call centre (MESO) does very little in the way of actively implementing health and safety policies in the workplace beyond the training session
Table 6: Effects of Call Centre Work on Employees' Health

\begin{tabular}{|l|l|l|l|l|}
\hline & $\begin{array}{l}\text { Tiredness \& } \\
\text { Fatigue }\end{array}$ & Stress & $\begin{array}{l}\text { Muscle } \\
\text { strain/fatigue }\end{array}$ & No Effect \\
\hline TELI & & $\begin{array}{l}\text { XXXXX } \\
\text { XXXXX } \\
\text { XXXXX }\end{array}$ & $\begin{array}{l}\text { XXXXXXX XXXXX } \\
\text { XXXXX }\end{array}$ & $\begin{array}{l}\text { XXXXX } \\
X\end{array}$ \\
\hline MESO & XXXXXX & XXXXX & $\begin{array}{l}\text { XXXXXXX } \\
\text { XXXXX }\end{array}$ & $X X$ \\
\hline
\end{tabular}

NB. ' $\mathrm{X}$ ' $=$ number of employees claiming to have experienced the specific OHS impacts.

conducted in the initial induction stage. Employees and supervisors therefore had little knowledge about how to go about dealing with these issues, and what role they play in the identification and management of hazards. Management, however, dismissed any responsibility in these respects, stating that the highly casual nature of employment lessened their health and safety obligations. This clearly breaches the Health and Safety in Employment (HASIE) Act, 1992.

The physical working environment in call centres also represents a number of risks for workers. Not only are call centre workers constantly interacting with customers in a highly repetitive manner, they are also required to simultaneously use telephone and computer equipment during the process.

This issue is more significant within the small call centre MESO, where all 14 of the employees interviewed drew significant attention to the poorly designed work-stations in reference to the muscular strain and fatigue they had experienced. Despite the risks posed by the working environment, this call centre has made little effort to minimise or remedy these problems. The equipment used by employees (chairs, tables, computers, etc) are based on a 'one-size fits all' mentality, and are lacking in adjustability and comfort. Furthermore, management appears to dismiss the notion that the working environment could play any part in diminishing the health of employees; stating that shifts are too short, and irregular for employees to be disadvantaged in any way. Again, the organisation has a legal obligation under Section 6 of the HASIE Act to take "all practicable steps" to prevent any mental or physical harm occurring to employees from the way the work is structured.

Key stakeholders, case study participants, and the literature (see ACA 1998; Richardson and Marshall 1999; Kinnie et al 2000; Richardson et al 2000; URCOT 2000; Wallace et al 2000; Batt and Moynihan 2002; Deery and Kinnie 2002; Holman 2002; Mulholland 2002; Paul and Huws 2002) also emphasise the issue of stress and fatigue in call centre workplaces. For instance, almost 50 percent of case study participants drew attention to emotional stress in the workplace as a result of employees having to deal with abusive customers on a day to day basis (refer to OSH Service's report entitled 'Healthy Work Managing Stress and Fatigue at Work', 2003). 
Working arrangements and the employment status of call centre employees are issues also requiring attention in order to improve health and safety outcomes. Although management from MESO insisted that shifts were too short to have any negative impacts, case study data confirms that employees are required to work long and unconventional hours on a regular basis. Furthermore, a strong correlation can be drawn between the working hours and negative outcomes such as fatigue and emotional stress.

Associations could also be drawn between working time issues and stress through interviews with TELI workers. All 9 of the core employees interviewed were dissatisfied having to work unsocial hours as a job requirement, but felt they had no other choice but to accept the inconvenient hours without penal rates, because of their disadvantaged status in the labour market. Christensen (1998) suggests these feelings can easily translate into a diminished sense of self-worth, feelings that are strongly predisposed to creating stress in the workplace.

We're the peasants and they (the management) are the landowners (TELI: Core).

You're just a voice on the phone for customers to vent their frustrations, you cant help being affected by it, it really messes with your emotions. (TELI: Non-Core Employee)

We are not the great of the great, we're the last off the ship (TELI: Core)

They're not here long enough for OSH to be an issue (MESO: Manager).

\section{Conclusion}

A number of significant issues emerged from this study, each representing some major implications for policy makers. For instance, although the call centres involved in the study differed significantly from one another, the use of non-standard employees was an integral aspect of both their employment practices. Furthermore, an examination of these non-standard employment forms, on the basis of a number of key themes, suggests that the phenomenon of precarious employment is a key feature of employment in the New Zealand call centre environment. However, the extent to which precariousness remains a feature of the call centre industry depends on how these issues are dealt with by the relevant parties. The longer these employment practices are allowed to continue, the more ingrained they will become in the call centre terrain, and the more difficult they will be to manage in future.

Finally, given the projected growth of the call centre industry, policy makers need to be mindful of the employment features that characterise this industry. In particular, greater attention needs to be paid to regulating the use of non-standard workers in this industry.

\section{Future Research}

Despite the useful insights derived, like many other types of qualitative research, this one was defined by a broad topic, meaning the phenomenon may not have been investigated in the amount of depth necessary, particularly given the number of indicators investigated. An important recommendation that can be made for future research is to examine each of the indicators and/or themes of precariousness independently, in order to develop a more profound understanding of the phenomenon.

In addition, while this study highlights the negative aspects of precarious work in call centres, there is some counter-arguments that suggest working in call centres may have certain benefits for some individuals, such as the ability to work flexitime and to re-start a working career (refer to Vivienne Hunt 'Call Centre Work for Women: Career or Stopgap?). Given that there is some debate regarding aspects of precarious work, there is a need for more empirical work that examines precarious work under different situations.

\section{Notes}

1. Using data from "The 2002 New Zealand Call Centre Industry Benchmark Study" involving surveys of 151 call centres, by ACA Research, an initiative of callcentres.net.

2. Only $55 \%$ of all non-core workers are unionised compared to $68 \%$ of all cores.

\section{References}

Ackroyd, S., and Hughes, J. (1981). Aspects of Modern Sociology: Data collection in Context, USA: Longman

Allan, C. (2000). The hidden organisational costs of using non-standard employment. Personnel Review, 29 (2): 188-206.

Atkinson, J. (1984). Manpower Strategies for Flexible Organisations. Personnel Management, August: 28-31.

Australian Communications Association [ACA] (1998) Call Centre Hang-ups - The Call Centre Agent Report, Sydney: ACA Research Pty Ltd.

Australian Communications Association (2003) The 2003 Australia Call Centre Industry Benchmark Study: an operational view of the call centre market, Sydney: call.centres.net.

Australian Communications Association (2002) The 2002 New Zealand Call Centre Industry Benchmark Study: an operational view of the call centre market, Sydney: call.centres.net. 
Bain, P., Bunzel, D., Mulvey, G., Hyman, $\mathbf{J}$ and Taylor, P (2000) Work organisation, control and the experience of work in call centres. Management Research News, 23 (9-11): 12-14.

Barker, K. and Christensen, K. (1998). Controversy and Challenges raised by Contingent Work Arrangements. Introduction in Barker, $\mathrm{K}$ and Christensen, K (eds). Contingent work. USA: Cornell University.

Barker, K. and Christensen, K. (1998a). Charting Future Research. chapter 13 in Barker, $\mathrm{K}$ and Christensen, K (eds), Contingent work. USA: Cornell University.

Bergstrom, O. (2001). Does Contingent Employment Affect the Organization of work? SALTSA Joint Programme for working life research in Europe, Sweden: Elanders Gotab.

Bernasek, A. and Kinnear, D (1999). Workers Willingness to Accept Contingent Employment. Journal of Economic Issues, 33 (2): 461-470.

Brosnan, P. (1995). Labour Markets and Social Deprivation, Inaugural Professional Lecture Series: Griffith University Faculty of Commerce and Administration.

Brosnan, P. and Walsh, P. (1996) Plus ca change...:The Employment Contracts Act and non-standard employment in New Zealand, 1991-1995, Labour, Employment and Work in New Zealand, Proceedings of the Seventh Conference, Victoria University of Wellington.

Buchanan R., and Koch-Schulte, S. (2000) Gender on the Line: Technology, Restructuring and the Reorganization of Work in the Call Centre Industry, Status of Women Canada - SWC.

Burgess, J. (1997). Part-time employment in Australia: unusual features and social policy issues. International Journal of Social Economics, 24 (7, 8, 9): 831-846.

Burgess, J., and Campbell, I (1998). The Nature and Dimensions of Precarious Employment in Australia. Journal of Labour and Industry, April, $8(3): 5-22$.

Burgess, J., and Strachan, G. (1999) 'The Expansion of Non-Standard Employment in Australia and the Extension of Employers Control' chapter 7 in Felstead, A., and Jewson, N (eds) Global Trends in Flexible Labour: Critical Perspectives on workand organisations. Hampshire: Macmillan Press.

Butcher, A (2002) A Review of the Literature on NonStandard Workand the New Economy Working Paper No. 9, Labour Market Dynamics Research Programme, Massey University.
Carroll, N. (1999). Non-standard employment: a note on levels, trendsand some implications. Labour Market Bulletin, p101-121.

Christensen, K. (1998). Countervailing Human Resource Trends in Family-Sensitive Firms' chapter 4 in Barker, $\mathrm{K}$ and Christensen, $\mathrm{K}$ (eds), Contingent work. USA: Cornell University.

Clements, E., Hobman, L., Rosier, P., and Tweedy, R. (2002) Flexible Employment, paper prepared for the New Zealand Work and Age Trust, Funded by the Government's EEO Contestable Fund.

Costello, A. (2001). Flexploitation Strategies: UK lessons from and for Europe. http://www.labour net.net/ukunion/0111/flexplot.html, Retrieved: 2 August 2003.

Cranford, C., Vosko, L., and Zukewich, N. (2003). The Gender of Precarious Employment in Canada. Industrial Relations, Fall Issue.

Deeks, J., and Rasmussen, E. (2001). Employment Relations in New Zealand, 3rd edition, Auckland: Pearson Education.

Deery, S., and Kinnie, N. (2002). Call centres and beyond: a thematic evaluation. Human Resource Management Journal, 12 (4), 3-14.

du Rivage, V L. (1992). New Policies for the Part-Time and Contingent Workforce, chapter 3 in du Rivage, V L. (ed). New Policies for the Part-Time and Contingent Workforce. USA: M E Sharpe.

Fallick, B (1999) 'Part-time work and Industry Growth' Monthly Labour Review, 122 (3): 22-29.

Felstead, A., and Jewson, N. (1999) (eds.). Flexible Labour and Non-Standard Employment: An Agenda of Issues, chapter 1 in Felstead, A., and Jewson, N, Global Trends in Flexible Labour: Critical Perspectives on work and organisations. Hampshire: Macmillan Press.

Future of Work Review [FOW] (2002) New Zealand Department of Labour.

Frenkel, S., Tam, M., Korzynski, M and Shire, K (1998). Beyond Bureaucracy? Work Organisation in Call Centres. The International Journal of Human Resources Management, 9 (6), 957-979.

Gilmore, A., and Moreland, L. (2000). Call centres: How can service quality be managed? Irish Marketing Review, 13 (1), 3-12.

Hipple, S., and Stewart, J. (1996). Earnings and Benefits of Contingent and Non-Contingent Workers. Monthly Labour review, October 1996: 22-30. 
Holman, D. (2002). Employee well being in call centres. Human Resource Management Journal, 12 (4): 35 51.

Horwitz, F., Allan, C., and Brosnan, P (2000). Flexible work practices: Perspectives from the Southern Hemisphere. South African Journal of Business Management, 31 (2): 76:84.

Houlihan, M. (2002). Tensions and variations in call centre management strategies. Human Resources Management Journal, 12 (4): 67-86.

Houseman, S. (1999). The Policy Implications of NonStandard Employment Arrangements. Employment Research, W.E. Upjohn Institute for Employment Reseach.

Houseman, S. (2001). Why Employers use Flexible Staffing Arrangements. Industrial and Labour Relations Review, 55 (1): 149-170.

Hunt, V (2004) Call Centre Work for Women: Career or Stopgap? Labour and Industry, 14 (3): 139-155.

Hutchinson, S., Purcell, J., and Kinnie, N (2000). The Challenge of the Call Centre. Human Resource Management International Digest, 8 (5): 4-7.

Hutchinson, S., Purcell, J., and Kinnie, N. (2000a). Evolving high commitment management and the experiences of the RAC call centre. Human Resource Management International Digest, 10 (1): 63-79.

International Labour Organisation (1993). Resolution Concerning the International Classification of Status in Employment Adopted by the fifteenth International Conference of Labour Statisticians. Bureau of Statistics, International Labour Organisation. http://www.ilo.org/public/english/ bureau/stat/res/icse.htm, Retrieved: 12 August 2003.

Kinnie, N., Hutchinson, S., and Purcell, J. (2000). Fun and surveillance: The paradox of high commitment management in call centres. International Journal of Human Resources Management, 11 (5): 967-985.

Kramar, R. (1998). Flexibility in Australia: implications for employees and managers. Employee Relations, $20(5): 453-460$.

Lipsig-Mumme, C. (1998). The Next Working Class: Precarious Employment, Community Unionism and New Organising Strategies in Canada. Centre for Research on Work and Society, York University: Canada.

Mangan, J (2003) Some Aspects of Non-Standard Employment and Multiple Job holding in Australia, Centre for Economic Policy Modelling, University of Queensland.
Markey, R., Hodgkinson, A., and Kowalczyk, J. (2002). Gender, Part-time Employment and Employee Participation in Australian Workplaces. Employee Relations, 24 (2): 129-150.

Marshall, C., and Rossman, G. (1995). Designing Qualitative Research 2nd edition, California: Sage.

Morley, M., Gunnigle, P., and Haraty, N. (1995). Developments in flexible working practices in the Republic of Ireland. International Journal of Manpower, $16(8)$ : 38-58.

Mulholland, K. (2002). Gender, emotional labour and team-working in a call centre. Personnel Review, 31 (3): 283-304.

Murtough, G., and Waite, M. (2001). A new estimate of casual employment?: Reply. Australian Bulletin of Labour, 27 (2): 109-118.

Nollen, S., and Axel, H. (1998). Benefits and Costs to Employers, chapter 5 in Barker, $\mathrm{K}$ and Christensen, $\mathrm{K}$ (eds.). Contingent work. USA: Cornell University.

Occupational Safety and Health [OSH] Service (2003) Healthy Work - Managing Stress and Fatigue at Work, 1st Edition. Department of Labour, OSH Service: Wellington.

Owens, R. J. (2001) The 'long-term or permanent casual'-an oxymoron or 'a well enough understood Australianism' in the law'? Australian Bulletin of Labour, 27 (2): 118 - 137.

Paul, J., and Huws, U. (2002). How Can We Help? Good practice in call centre employment. Second Draft Report for the TOSCA Project, Analytical Social andEconomic Research Ltd

Patton, M. Q (1987) How to use qualitative methods in evauation. Newbury Park: Sage Publications Inc.

Prabhakar, P., Sheehan, M., and Coppett, J (1997). The Power of Technology in Business Selling: call centres. The Journal of Business and Industrial Marketing', 12 (3/4): $222-231$

Quinlan, M.., Mayhew, C., and Bohle, P. (2000) Contingent Work: Health and Safety Perspective. Paper presented to the Conference on 'Just in Time Employed - organisational, psychological and medical perspectives', Dublin.

Quinlan, M.., Mayhew, C., and Bohle, P. (2000) Contingent Work: Health and Safety Perspective. Paper presented to the Conference on 'Just in Time Employed - organisational, psychological and medical perspectives', Dublin.

Quinlan, M., Mayhew, C., and Bohle, P. (2000a). The Global Expansion of Precarious Employment, Work Disorganisation and Consequences for Occupational Health: A Review of Recent 
Research. International Journal of Health Services, 31 (2): 335-414.

Quinlan, M. (2003) 'Regulating Flexible Work and Organisational Arrangements' paper presented at Australian OHS Regulation for the 21st Century conference July 21-22, Gold Coast.

Quinlan, M. (2003a). The Global Expansion of Precarious Employment: Meeting the Regulatory Challenge. http://www.actu.asn.au/public/ohs /quinlan.html, Retrieved: 2 September 2003.

Reilly, P. (2001). Flexibility at Work: Balancing the interests of employer and employee. Great Britain: Gower Publishing.

Richardson, R. (1998). The competitiveness project: Developing the Call Centres industry in the North East. University of Newcastle, UK: Centre for Urban and Regional Development Studies.

Richardson, R., and Marshall, J. (1999). Teleservices, call centres and urban and regional development. The Service Industries Journal, 19 (1): 96-117.

Richardson, R., Belt, V., and Marshall, J. (2000). Taking calls to Newcastle: the regional implications of the growth in call centres. Regional Studies, 34 (4): 357-370.

Rogers, G., and Rogers, J. (1989). Precarious Jobs in Labour Market Regulation: The Growth of Atypical Employment in Western Europe, Belgium: International Institute for Labour Studies.

Rosenberg, S., and Lapidus, J. (1999). Contingent and Non-Standard Work in the United States: Towards a More Poorly Compensated, Insecure Workforce. chapter 4 in Felstead, A., and Jewson, N (eds.) Global Trends in Flexible Labour: Critical Perspectives on work and organisations. Hampshire: Macmillan Press.

Rudman, R. (2000). Human Resources Management in New Zealand. NZ: Pearson Education.

Sheridan, A., and Conway, L. (2000). Workplace flexibility: reconciling the needs of employers and employees. Women in Management Review, 16(1): 5-11.

Shire, K., Holtgrewe, U., and Kerst, C. (2002). Reorganising Customer Service Work: An Introduction, chapter 1 in Holtgrewe, U., Kerst, C and Shire, K (eds.) Re-organising Service Work: Call Centres in Germany and Britain. England: Ashgate.
Smithson, J., and Lewis, S. (2000). Is Job Insecurity Changing the Psychological Contract?. Personnel Review, 29 (6): 680-702.

Stake, R. (2000). Case Studies, chapter 16 in Denzin, N. and Lincoln, Y (eds.) (2000) Handbook of Qualitative Research. : California: Sage.

Taylor, B., and Bain, P. (1999). An 'Assembly Line in the Head': Work and Employee Relations in the Call Centre. Industrial Relations Journal, (30) 2: 101-117.

Tregaskis, O. (1997). The "non-permanent" reality! Employee Relations, 19 (6): 535-554.

Tucker, D. (2002). 'Precarious' Non-Standard Employment - A Review of Literature. Labour Market Policy Group, Department of Labour: Wellington.

Union Research Centre for Organisation and Technology [URCOT] (2000). Call Centres: What kind of future workplaces? RMIT School of Social Sciences and Planning, Victorian Trades Hall Council.

Vosko, L. F. (2000). Temporary Work: The gendered rise of a precarious employment relationship. Toronto: University of Toronto Press.

Wallace, C., Eagleson, G., Waldersee, R. (2000). The Sacrificial HR strategy in Call Centres. International Journal of Service Industry Management, 11 (2): 174.

Watson, A., Bunzel, D., Lockyer, C., and Scholarios, Dora. (2000). Changing constructions of career, commitment and identity: The call centre experience. Management Journal News, 23 (9-11): 158-160.

Watson, I., Buchanan, J., Campbell, I., and Briggs, C (2003). Fragmented Futures: New challenges in working life. Sydney: Federation Press.

Watts, R. (2001). The ACTU's response to the growth in long-term casual employment in Australia. Australian Bulletin of Labour, 27 (2):137-150.

Yin, R. (1994). Case Study Research: Design and Methods, Second edition, California: Sage.

Zeytinoglu, I. U., and Muteshi, J. K. (2000). Gender, Race and Class Dimensions of Non-Standard Work. Industrial Relations, 55 (1): 133-167. 